\title{
U.S. Government Factors Influencing an Expansion of Study Abroad in the Middle East/North Africa
}

\author{
Cara Lane-Toomey \\ AMIDEAST
}

During the past 60 years, United States foreign policy has at times dictated the terms for support of international education. Beginning in the late 1950s, federal legislation has helped to create opportunities for young U.S. students to learn about areas of the world that had been largely neglected by providing federal funds to support certain aspects of higher education. As the United States continued to grow as a world power throughout the later part of the twentieth century, government funding for international education grew more closely connected to its national security needs. Federal funds have contributed to the growth of Area Studies and studying Less Commonly Taught Languages (LCTLs).

These legislative developments have also been foundational in the expansion of study abroad. The tradition of study abroad by U.S. students was born in the early twentieth century and has become a staple of the higher education experience over the last several decades. The solidification of study abroad as an educational opportunity offered by U.S. institutions has been influenced by the development of Area Studies, changing geo-political interests, and the growth in governmental funding for area and language study. In addition, federal funding has contributed to the expansion of study abroad in non-traditional, or less common, destinations outside of Europe. Data from the Institute of International Education show that there are increasing numbers of U.S. undergraduate students studying abroad in less common destinations ${ }^{1}$, including the Middle East and North Africa (MENA) region ${ }^{2}$. Within the last ten years the U.S. study abroad population selecting the MENA region has grown by over 500\% from 694 students in 2000/01 to 4,485 in 2008/09 (Open Doors, 2009).

This remarkable growth is occurring at the same time as national security and foreign policy goals of the United States have become increasingly focused on the MENA region. Despite the large amount of research on outcomes and educational approaches used in study abroad in general, there is little literature which addresses the relationship between the U.S. government and study abroad in the MENA region. This essay addresses the research question "In what ways has the U.S. government's focus on national security in regards to the MENA region influenced undergraduate students to choose the MENA region as their study abroad destination?" This study examines the history of federal legislation in relation to higher education in order to understand how the U.S. government has influenced the development of formal Area Studies Programs and study abroad opportunities in less common destinations. Further, this research analyses data collected from a cross-sectional survey and focus groups with current U.S. undergraduate study abroad students ${ }^{3}$ in order to discuss the influence of factors such as career motivations, scholarship support, and attitudes 
about U.S. national security on a student's decision to study abroad in the MENA region rather than a more common destination. These factors were selected in order to better understand if students who select the MENA region are more influenced by government related factors than their counterparts who choose to study abroad in Western Europe or Australia.

\section{History}

In order to better understand the factors leading to an increase of study abroad students in the MENA region, it is imperative to first look at the history of the outgrowth of study abroad in this particular part of the world. This study explores how government funding for area and language education has been largely based on the national security concerns of the United States over the last 60 years. Further, government funding for Area Studies and LCTLs has facilitated the growth in study abroad in less common destinations, such as the MENA region. This background is intended to show how U.S. foreign policy has shaped support for international education, which has in turn influenced the numbers of students studying abroad in the Middle East and North Africa.

\section{History of Funding for Area Studies and Language Study in the U.S.}

Prior to the 1950s very few U.S. universities were able to produce specialists in area studies outside Western Europe (Wiley 2001, p. 12). In 1947 "there were only fourteen language and Area Studies programs on all U.S. campuses - six for Latin America, four for East and Southeast Asia, three for East Europe, one for South Asia, and none for Africa or the Middle East (Wiley 2001, p. 12). In the years following World War II, a large number of new nation states emerged and U.S. interests became more global. In tandem with these developments, a new academic field of study emerged, Area Studies, which met the need for knowledge and specialists on areas of the world that were becoming more politically active. Area studies differs from other disciplines such as History, Anthropology, or Political Science in that it focuses on the development of a "clear subspecialty in a language or area". This contrasts with more conventional fields where one may only have "a passing acquaintance with one or more areas of the globe" (Brecht \& Rivers 2000, p. 6).

Formal Area Studies programs at U.S. universities expanded largely because U.S. legislators saw an increasing need for global specialists. The inexorable rise of the Soviet Union, exemplified by the Soviet Sputnik space mission, cemented Area Studies' position in U.S. education and its global role. The Eisenhower Administration developed a legislative plan in response to the launch of Sputnik which "focused on improving scientific expertise, but it also included graduate fellowships and grants to universities for language study" (O'Connell \& Norwood 2007, p. 269). The end result, the National Defense Education Act (NDEA), was introduced in Congress in 1958. The objective of the legislation was clearly tied to national security needs of the United States. The law stated that the purpose of NDEA was "to insure trained manpower of sufficient quality and quantity to meet the national defense needs of the United States" (Public Law 85-864). A key section of NDEA is Title VI, which provided federal funding for language and Area Studies at U.S. universities. Originally approved as a four-year program, it has been renewed continuously throughout the succeeding five decades. In addition to Title VI, several other pieces of legislation were passed in the 1990s and 2000 s in order to provide funding for language and area specialty training; including the Boren Bill 
and the National Security Language Initiative (NSLI). In view of the extremely limited options for foreign language training in the U.S., NDEA focused specifically on increasing proficiency in LCTLs, defined as Arabic, Chinese, Hindi-Urdu, Japanese, Portuguese, and Russian (Wiley 2001, p. 13). These languages have been acknowledged as particularly time consuming languages to master for native English speakers (c.f. O’Connell \& Norwood 2007, p. 45).

Perhaps the most lasting and important outcome of the initial passage of Title VI was the transition from private-sector support (Wiley 2001, p. 14) to federal support of Area Studies, fostering a proliferation of university programs. This new relationship also refocused the field's purview and henceforth, Area Studies discussions at the federal level almost "always involved discussions of global politics and the usefulness of Area Studies for U.S. interests" (Ludden 2001, p. 3).

Although widely supported during the late 1950s and 1960s, federal funding for Area Studies came under scrutiny in the 1970s and 1980s. The Nixon administration unsuccessfully attempted to halt federal funding for Title VI, purporting that Area Studies had already gained sufficient momentum to sustain itself (Keller \& Frain 2010, p. 29). However, events such as the Vietnam War, the 1979 Iranian hostage crisis, and the continuing Cold War complicated the U.S.'s geo-political relations and international standing. Title VI programs and Area Studies were increasingly seen as a necessary way to address the strategic U.S. interests. In 1980 Congress incorporated the provisions of Title VI of NDEA into the Higher Education Act (HEA): "International and Foreign Language Studies" (O'Connell \& Norwood 2007, p. 278) and established a permanent statutory home for support for area and language studies. Further, amendments were added which injected more of a business focus into Title VI programs as a result of a growing concern about the U.S. competitiveness with Asia and Western Europe (O'Connell \& Norwood 2007, p. 280). This inclusion reshaped Title VI funding, which now focused on helping students to obtain knowledge critical not only to national security, but also economic security. This alteration is indicative of the government's desire to secure financial interests, and in particular relation to the MENA region, this change came as the U.S. was growing more dependent on Middle Eastern oil sources. Another noteworthy change to the legislation included dropping the service requirement of recipients of Title VI funds in order to "encourage individuals seeking careers outside teaching—such as business— to participate in these programs” (O’Connell \& Norwood 2007, p. 279).

More changes came to legislation related to area and language studies following the fall of the Soviet Union and the consequent refocusing of national security objectives. In 1991 the Department of Defense (DoD) began to implement the National Security Education Act (NSEA) ${ }^{4}$, which came to compete with Title VI as a source for foreign language study. The primary component of NSEA was the National Security Education Program (NSEP) which mandates that those who receive funding for study make an effort to find employment in the federal government, particularly in national security positions. Those individuals who fail to meet the service requirement are then required to "repay the amount of assistance given to them, plus interest" (Riddle 1992, p. 4).

One of the significant distinctions between Title VI and the NSEP (Boren) funds is the 
government service requirement for those who receive NSEP funded language and area specialty training. The original Title VI legislation required recipients in certain programs to 'repay' their assistance by finding employment in public service, but those requirements were later dropped. In contrast, the NSEP funds are "specifically aimed at developing a pipeline of individuals with specific talents into jobs at federal bureaucracies" (O’Connell \& Norwood 2007, p. 81). Second, the NSEP had a more clearly defined national security application. Funds are concentrated on a limited set of critical languages and are applied to the "current language needs in the area of national security, the critical foreign languages spoken in nations that are important allies or actual or potential adversaries of the United States" (O'Connell \& Norwood 2007, p. 63). These particular provisions raised concerns about apparent relations with the CIA (Riddle 1992, p. 7), causing the Middle East Studies Association (MESA) and other Area Studies associations to reject NSEP funding. Lastly, whereas most of the Title VI programs take place in the United States, NSEP fellows are more likely to spend long periods of time studying abroad.

Despite its initial embrace by legislators, within four years Congress began to express concern that "the government was not benefiting enough from the program" and attempted to require not just government service, but service with either the DoD or intelligence agencies (Desruisseaux 2000 , p. 3). Although the alteration was softened by the efforts of Senator Paul Simon (D-IL), the service requirement was changed to require recipients to repay their fellowships through service "in any federal agency with national-security responsibilities" (Desruisseaux 2000, p. 3).

Many scholars have marked events of September 11, 2001 as a critical point in U.S. history in regards to the explosion of general academic concern about the MENA region and the need for governmental personnel who are well trained in critical languages and Middle East Studies. Following 9/11, funding for Title VI programs increased by $10 \%$ and has been used widely to support the expansion of Arabic language learning and teaching (c.f O'Connell \& Norwood 2007, p. 131). In addition to increases in Title VI funding from the ED (Department of Education), the DoD continued to fund its own grants for educating students in LCTLs through Boren Fellowships. Funding from the DoD has continued partially as a way to ensure that if Title VI was not providing a path for recipients to governmental service there would be other funds which would achieve this goal. Despite the promise offered by the increase in funds following the events of 9/11, the 2011 congressional budget has mandated a 40\% (\$50 million) cut to Title VI and Fulbright funds. MESA has spoken out against such proposed cuts and urged that the U.S. government

recognize the important role these programs have played in developing over the long term our national security, our economic competitiveness and our reservoir of leaders (including the current Secretary of Defense) and specialists. As events continue to unfold in our particular area of expertise, we see no future that is without the need of experts in the languages and cultures of the Middle East. To turn off the tap of the pipeline now would inflict incalculable damage to our ability to meet the challenges of the future. Once gone, these programs will not easily be resurrected (MESA, 2011, n.p.). 
Since 2003, NSEP grants have been merged into the National Flagship Language Program (NFLP). In a 2006 address at the State Department, President George W. Bush announced a series of additional initiatives which would become known as the National Security Language Initiative (NSLI), which focused on increasing capacity in LCTLs such as Arabic, Chinese, Farsi, Hindi, Urdu, Turkic, and Russian (O'Connell \& Norwood 2007, pp. 4-5). The proposals of the initiative included increasing the number of scholarships for study abroad in critical languages, increasing funding of the NFLP to $\$ 13.2$ million in order to help several thousand students reach an advanced proficiency in LCTLs, and increasing the number of Gilman scholarships which help students with financial need finance language study abroad (Kolb 2009, p. 51).

Since the early 1990s and continuing into the present period, funding for Area Studies and LCTLs has been provided by the government under shifting purposes. There has been much debate as to what extent LCTLs and Area Studies should be supported for educational purposes or as a tool of national security. Although there continues to be no public service component to Title VI programs, there has been increasing discussion about the limited number of Title VI beneficiaries who go on to work for the federal government. In 2004 Title VI appropriations covered approximately $10 \%$ of the cost of U.S. Area Studies programs, yet only $3.2 \%$ of graduates from such programs enter federal government or military service (Kramer 2004, n.p). Particularly in the years following 2001, both the General Accounting Office $(\mathrm{GAO})^{5}$ and the 9/11 Commission argued that insufficient personnel "hindered US military, law enforcement, intelligence, counterterrorism, and diplomatic efforts" (O’Connell \& Norwood 2007, p. 47).

The essence of this debate is whether or not it is the role of the ED to meet the federal government's need for language specialists. Critics of Title VI such as Kenneth Whitehead, a former director of international education programs in the ED, have argued that the main justification for this funding is still "the production of foreign-language and area specialists, trained, competent, and willing to help serve the defense and security needs of the United States” (Whitehead 2004, n.p). Others may counter this argument by stating that the legislation has morphed over the years and that other purposes such as development of language and area centers for the sake of knowledge should be seen as paramount to producing training for federal agencies.

Although critics argue that Title VI funding has been inadequate in providing government specialists, the importance of the legislation should not be understated. One of the most significant impacts of Title VI has been that it has "helped define the development of language and Area Studies programs in this country" (Hines 2001, p. 9). Title VI funded centers around the U.S. are currently offering courses in more than 250 LCTLs (O’Connell \& Norwood 2007, p. 3). A 2008 report by the ED noted that "although fewer than $3 \%$ of the nation's higher education institutions that offer modern foreign languages have Title VI national resource centers, these institutions represent $23 \%$ of all undergraduate enrollments in the LCTLs and 59\% in the Least CTLs" (Office of Postsecondary Education 2008, n.p.). It has been argued that without Title VI funds, many, if not most, of the programs which focus on the LCTLs would not have been developed or maintained throughout the years (Brecht \& Walton 2001, p. 103). Another impact is that the NDEA and accompanying Title VI established a new sort of relationship between the federal government and institutions of higher 
education, shifting funding for area studies programs from private institutions to the federal government. A third impact of Title VI funding has been serving "national security needs, in the long term, by developing and sustaining area and international knowledge" (O'Connell \& Norwood 2007, p. 30). Title VI's focus on training experts, not only in language, but in the culture, economics, and politics of world regions, provides a base of experts on a variety of areas, not just those in which the U.S. has a current interest.

Although Area Studies owes much of its raison d'etre to the federal government, as the field has grown and developed over the years, specialists have diverged from the historical idea that their primary purpose was to serve national security interests. Particularly in current times, when the U.S. continues to be engaged in foreign wars in the greater Middle East region, this debate will likely carry on. Academics and lawmakers will continue to explore the best way to both support Area Studies as an academic field as well as ensure a cadre of specialists in critical regions who are willing to serve the government.

\section{Middle East Studies emerges as a part of Area Studies}

One of the major sub-disciplines of the Area Studies field is Middle East Studies, which was previously known as "Oriental Studies," a largely historical field which developed out of "Biblical studies and Semitic philology" (Mitchell 2004, p. 77). The roots of Middle East Studies in the U.S. began to form in 1946 with the creation of international administration at Columbia University and language training programs for the Army at universities in New Jersey, Indiana, Michigan and Pennsylvania (Hajjar \& Niva 1997, n.p.). Once established, Middle East Studies as a field of study exploded. By 1965 there were 180 colleges and universities in the U.S. which offered classes on the Middle East. There were additionally eight area centers (supported by Title VI funding) which focused on studying the modern Middle East (Hajjar \& Niva 1997, n.p.). As of $2003^{6}$ there were 127 Middle East Studies graduate and undergraduate programs.

Middle East Studies, as we know it today, was made possible largely because of Title VI funding. Additionally, NSEP and NLSI legislation has provided further support for students to study the Arabic language and subjects related to the MENA region. In the last decade, there has been not only increased funding for Arabic and Middle East Studies, but also more opportunities for university level students to be exposed to Middle East issues. One of the ways in which students have been exposed to Middle East issues is through the Fulbright Scholar Program 7 , which aims, in part, "to bring scholars from the Middle East to address American audiences of non-Middle East specialists" (Khoury, 121). Phillip S. Khoury has argued that the presence of Fulbright Scholars on campus has a positive impact on U.S. institutions without a Middle East Studies department in that they expose "Americans to more nuanced views about that region, its politics, and often misunderstood issues such as religion and terrorism" (Khoury, 122). As federal funding for Arabic and Middle East Studies has increased and more young people are exposed to Middle East issues on their home campuses, there has been a corresponding increase of students choosing to study abroad in the MENA region. 


\section{U.S. Students Abroad}

In its current usage, study abroad refers to educational endeavors which take place outside of a student's home country and which "results in progress toward an academic degree at the student's home institution" (Forum on Education Abroad). In the years following the events of September 11, 2001, study abroad has experienced considerable growth. In the 2007/08 school year 262,416 U.S. students gained credit for studying abroad (Open Doors 2009), a 144\% increase in just ten years (IIE 2007, p. 6). In 2006, $91 \%$ of U.S. universities offered study abroad programs, a $43 \%$ increase from 2000 (Hoffa \& DePaul 2010, p. 2).

Most students choose to study in common destinations such as those in Western Europe or Australia and there has been little change in the top ten destinations for study abroad in many years (Open Doors 2009 and 2010). Many study abroad professionals have argued that the persistent focus on studying abroad in Western Europe "has severely curtailed the capacity of study abroad to prepare students, and by extension the nation itself, for the global forces and realities that will shape life in this century" (Hoffa \& DePaul 2010, p. 2). These trends are changing. In the 2007/08 school year, there were $20 \%$ increases in the number of students traveling to China, Argentina, South Africa, Ecuador, and India (Goodman 2009, p. ix). According to the IIE these increasing numbers reflect "the trend in recent years for more students to study in countries beyond the traditional study abroad destinations in Western Europe" (IIE 2010b).

The MENA is one area of the world which has experienced notable growth in study abroad participation. In the 2000/01 school year there were only 694 students studying in the MENA region, increasing to 4,485 students in the 2008/09 school year (Open Doors 2009). This represents an astonishing 546\% increase in just eight years. The destinations in the MENA region with the greatest number of study abroad students in the 2008/09 academic year included Egypt (1,781), the United Arab Emirates (955), Morocco (865), and Jordan (483) (Open Doors 2009).

\section{Study Abroad and Federal Legislation}

Given the growing geo-political role of the U.S., perspectives on the purpose of study abroad began to change in the middle part of the $20^{\text {th }}$ century. During the 1920 s, study abroad was seen generally as a means for students' personal development, but as the U.S. became more powerful in the 1950s study abroad "took on a new political prominence" (Keller \& Frain 2010, p. 16). As mentioned above, during the past five decades there have been several government initiatives which have provided funds to institutions of higher education in order to enhance their contribution to national security by supporting area and language specialty training. Area Studies centers often worked hand in hand with study abroad. Some centers use study abroad opportunities as ways to expand their course offerings to Area Studies majors, thereby further integrating study abroad experiences into the achievement of formal degrees. Other federal initiatives such as the NSEP (1991), the NSLI (2006), and the Gilman Scholarship (2000) have been effective in encouraging study abroad to uncommon destinations by exposing students to LCTLs and providing scholarship funds for study in areas where those languages are spoken. 
Nominal and scholarship support from the U.S. government, which is aimed at increasing study abroad specifically in the MENA region, can be found in the Intelligence Reform and Terrorism Prevention Act of 2004 as well as Boren Fellowship funding. The former calls for an expansion of U.S. exchange programs in the Islamic World and states that the government should "promote engagement with people of all levels of society in countries with predominantly Muslim populations" and increase investment in people-to-people programs (U.S. Congress S. 2485). In addition, during the last ten years, Boren Fellowships have reflected a growing focus on the Arabic language. Although China has been the most common destination for recipients of NSEP funds for several years, "it is interesting to note that four of the top five countries in 2007 are in the Near East" (NSEP 2007, p. 13). Of the 149 fellows in 2008-09, 50 studied Arabic, making it the most common language supported by these funds (NSEP 2009, p. 11). In 2008, 35\% of all fellowship recipients studied in the MENA region, a percentage that far outweighs that of the overall study abroad population in the region which is less than two percent of the worldwide total (IIE 2009a, p. 19). Like Area Studies, there is a long history of linkages between study abroad and the foreign policy interests of the U.S. government. As U.S. foreign policy and international relations have increasingly focused on the MENA region, there has been a precipitous growth in funding and support for study abroad in this region.

Without Area Studies, and more specifically Middle East Studies, U.S. university students would have very limited exposure to courses addressing the Middle East, Islam, and the Arabic language. Furthermore, federal legislation that has connected higher education to national security interests has increased the number of financial incentives to students willing to study in less common destinations such as those in the MENA region. In essence, these pieces of legislation have "introduced U.S. political interests into the broader picture of incentives to participate in study abroad" (Ogden, Soneson \& Weting 2010, p. 196). These federal expenditures have continuously raised philosophical questions amongst study abroad professionals, similar to those broached by Area Studies experts. Key among these is the question as to whether study abroad should be an undertaking that is intended to serve national objectives (Larsen \& Dutschke 2010, p. 346). There are no mutually agreed upon answers to these questions, but as the trend of study abroad grows these questions will need to be addressed by administrators and institutions.

\section{Literature Review}

Study abroad research tends to focus on the effectiveness and best practices of study abroad programs and outcomes for study abroad students, including factors such as personal development and global awareness (Bradshaw Durrant \& Rasmussen Dorius, 2007; Chieffo \& Griffiths, 2004; Daly \& Barker, 2005; Garver \& Divine, 2007; Van Hoof \& Verbeeten, 2005; Williams, 2005). A small body of research is emerging which addresses alternative subjects, including topics such as the motivation for students to study abroad, outcomes of programs with varying duration, and the benefit of study in less-common versus common destinations (Albers-Miller, Prenshaw \& Straughan, 1999; Eder, 2010; Garver \& Divine, 2007; Goldstein \& Kim, 2006; Relyea, Cocchiara \& Studdard, 2008; Salisbury, Umbach, Paulsen \& Pascerella, 2008; Sanchez, Fornerino \& Zhang, 2006; Wells, 2006). Despite this broader scope of research, there is a gap in the literature explaining precisely how 
U.S. undergraduate students choose their particular study abroad destinations. Further, little research has examined a growing trend of U.S. students selecting more non-traditional, or less-common, destinations outside of Europe. Literature related to study abroad in MENA is particularly sparse but has included discussions of expanding study abroad in the MENA region (IIE, 2009b) and language learning in the region (Ferguson, 1964; Palmer, 2012-13; Dewey, Belnap, Hillstrom, 2012-13; ). There continues to be a lack of information regarding what factors influence choice to study in this particular region. Lastly, there is no research and only limited anecdotal evidence which addresses the impact of government related factors such as career intentions, scholarship support, and concerns for U.S. national security on the choice of study abroad destination.

This research is based on a theoretical model which takes into account expectancy, student choice, and human capital theories. Building on previous literature (Bourdieu, 1986; Calhoun, LiPuma \& Postone, 1993; DesJardins \& Toutkoushian, 2005; Manski, 1993; Perna, 2006; Salisbury et al 2008, Sanchez et al 2006, and Vroom 1964), this research examines how certain experiences, which are defined as adding cultural and social capital, in addition to attitudes and future motivations affect a student's choice of study abroad destination. In order to address the research question of how the U.S. government's focus on national security in regards to the MENA region has influenced students to select this region as a study abroad destination, the results presented here will focus on the following factors: economic capital (scholarship support), motivations (career intentions), and attitudes (concern for U.S. national security).

\section{Research Design}

\section{Sample}

This study examines several concepts drawn from a survey of U.S. study abroad students in the MENA region and in destinations in Western Europe and Australia conducted during the fall of 2010. The students in the MENA region were participating primarily in programs in Egypt, Jordan, and Morocco. These three countries were selected because nearly $80 \%$ of those students who choose the Middle East as a destination come to one of these destinations (IIE 2009b, p. 7). These responses are compared with those of students currently studying in common destinations, in order to see if the factors which influence destination choice differ between the two groups.

Based on internet searches and contact with study abroad programs located in the MENA region, thirteen study abroad programs in Egypt, Jordan, or Morocco were identified. Ten of these programs agreed to have their students participate in the survey, focus groups, or both. In addition, 104 U.S. universities which had both study abroad offices and publicly available email addresses were contacted. Twenty one forwarded a link of the online version of the survey to all current study abroad students from their institution. No focus groups were conducted with students in common study abroad destinations.

\section{Measurement}

A survey of 27 questions composed of multiple choice, short answer, and ordinal scale formats was administered to the participating U.S. study abroad students. The survey was distributed in two 
self-administered formats. Online surveys were available for those in common destinations. Both hard-copy and online surveys were administered to students in the MENA region. Although a number of factors related to destination choice were measured by the survey, this study focuses on three which are related to the research question: career intentions, scholarship support, and concern for U.S. national security.

In addition to the survey data, this research also collected information from students by employing focus groups with several programs in the MENA region. An interview guide was used which contained questions about perceived influences on a student's decision. These responses, when combined with the quantitative data collected through a cross sectional survey, provide a more holistic view of the ways in which career intentions, scholarship support, and concern for U.S. national security influenced the choice of the MENA region as a study abroad destination.

\section{Analysis and limitations}

Two descriptive statistics, frequency distributions and cross-tabulations were employed in the data analysis process. Independent variables were cross-tabulated with dependent variables (destination choice) and the Chi-Squared test for independence was run for each cross-tabulation. The findings presented below are based only on students participating in programs in ten programs in the MENA region and those in databases of 21 U.S. study abroad offices. The data collected therefore cannot necessarily be extrapolated to larger populations. Despite this limitation, given the large number of respondents and the diversity of the geographic locations of their home school, the findings can lay the foundation for future research on government factors influencing the study abroad destination choice U.S. students.

\section{Career Intentions, Scholarship Support, and Concern for U.S. National Security}

This research examined career intentions as one of the possible motivations for studying abroad. Although career selection is a complicated process which often changes throughout a lifetime, there are several points in which students make choices about their vocation, times often referred to as an "explicit decision phase" (Sauermann 2004, p. 274). U.S. undergraduate study abroad students are typically in their junior year of college, and thus are at a critical decision phase in which they experience pressure to make choices about their career goals. Career intentions can be defined as a student's preferred fields of work, types of organizations to work for, and specific jobs desired.

This study also examined the type of scholarship support some students receive to assist them with their study abroad experience. Several federal scholarship programs such as the Boren Scholarship (funded by NSEP) and the Gilman Scholarship encourage study abroad to uncommon destinations by exposing students to LCTLs and providing scholarship funds for study in areas where those languages are spoken. Since the fiscal year 1994, the NSEP has "expended \$2 million each year on Boren Scholarships for undergraduate students" who study abroad in regions which are deemed critical to U.S. national security (Larsen \& Dutschke 2010, p. 345). In addition to these programs, the Benjamin A. Gilman International Scholarship Program provides funds to support undergraduate study abroad. The funds are specifically designed for undergraduate students who receive Pell Grant funds in order to help them study abroad in multiple destinations around the 
world. Those awarded the Gilman funds are additionally eligible "to receive an additional $\$ 3,000$ Critical Need Language Supplement" (IIE 2010a, n.p.). There are over 50 languages that are considered critical by the Gilman program including: Arabic, Chinese, Turkic, Persian, Indic, Korean, Russian, and Swahili.

Concern about U.S. national security was examined as a measure of attitudes which influence study abroad destination choice. Following the events of $9 / 11$, there has been an increased sense among lawmakers and the general public that the national security of the United States is threatened. National security, intelligence, and homeland security have become increasingly understood as intertwined subjects (Spracher 2009, p. 10). Research has demonstrated that national interests and approaches to national security can shape public opinion about international issues (Brewer 2006, p. 99). In addition, these attitudes may also have an effect on behavior such as aversion to interact with certain groups of people, career goals, or willingness to travel abroad.

\section{Results}

\section{Survey}

A total of 601 valid responses to the survey were received from online $(65 \%)$ and hard copy $(35 \%)$ versions. responses to the survey were nearly equally divided between the two destination categories. Forty-six percent of the sample $(n=275)$ were studying in the MENA region and 54\% $(n=326)$ were enrolled in programs in Western Europe or Australia. Respondents were studying abroad in 20 different countries, with large numbers of respondents indicating their study abroad destination as Egypt, Jordan, Morocco, England, Spain, France, Italy, or Australia. Of the valid responses to this survey, $70 \%$ were female, $29 \%$ male, and less than $1 \%$ transgender; closely mirroring that of the larger U.S. study abroad population. Similar to the greater U.S. study abroad population, a majority (78\%) of this sample was Caucasian.

This research examined the relationships between career intentions and study abroad destination choice by analyzing data regarding preference for intended type of organization to work for, career fields, and specific job desired in five years. When examined by destination of study abroad, there were notable relationships with types of organizations students wish to work for in the future, $\chi^{2}$ $(3, N=597)=75.52 p<.001$. Students in the MENA region were more likely to want to work for the government, with $35 \%(\mathrm{n}=91)$ of them noting this as the preferred type of organization as compared to $10 \%(\mathrm{n}=32)$ of students in common destinations.

Survey participants were given a nominal list of 19 specific career fields and one 'other' category. They were asked to rank their top three preferences for the general career fields they would like to pursue. Respondents' answers were re-coded to see if they listed in their top three choices one of five fields related to governmental careers (foreign policy, international relations, national security, and public policy). The data indicates that there is a relationship between students intent to pursue certain fields and their choice of study abroad destination. Of the four career fields related to the U.S. government, students in the MENA region more frequently selected foreign policy $\left(\chi^{2}(1, N=\right.$ $594)=66.83 p<.001)$, international relations $\left(\chi^{2}(1, N=594)=37.81 p<.001\right)$, and national 
security $\left(\chi^{2}(1, N=594)=47.37 p<.001\right)$ than students in common destinations. They were not more likely to select public policy as a career field $\left(\chi^{2}(1, N=594)=1.35 p=.245\right)$.

Students were also asked to indicate the specific job they would prefer to have in five years. Eighty-four different jobs were noted by respondents. For students who chose the MENA region as their study abroad destination, two commonly noted jobs (State Department employee and military intelligence officer) are related to work for the U.S. government and were more commonly noted by students in the MENA region, $\chi^{2}(1, N=394)=80.33 p<.001$. This evidence indicates a relationship between intention to pursue a career within the U.S. government and choice of the MENA region as a study abroad destination.

This research further investigated the relationship between scholarships and study abroad destination choice by asking students to indicate if they had received scholarship support, the name of their scholarship, and if they believe they would have studied abroad if they had not received the financial support. MENA students were somewhat more likely to have received scholarship support, $\chi^{2}(1, N=588)=5.67 p=.017$. Half $(\mathrm{n}=136)$ of those in MENA destinations indicated they had received a fellowship or scholarship to support their study abroad experience. In addition, a large percentage of students $(34 \%, \mathrm{n}=44)$ in the MENA region believed they would not have studied abroad had they not received scholarship funds in comparison with $20 \%(n=27)$ of students in common destinations.

If students indicated they had received financial support, they were further asked to list the name of the scholarship. Of the responses, there were 54 different scholarships listed. This research was particularly interested in the relationship between receipt of Boren, Gilman, and military scholarships and study abroad destination choice. Responses were re-coded into four categories separating these three scholarships from all other scholarships received. Of the scholarship recipients, students in the MENA region were more likely to have received government scholarships, $\chi^{2}(2, N=$ 223) $=8.19 p=.017^{8}$. Students studying abroad in the MENA region received both more Gilman scholarships (11\% compared to $4 \%$ in common destinations) and Military Scholarships (7\% as compared to $2 \%$ in common destinations). In addition, $9 \%$ of scholarship recipients in the MENA region were supported by Boren scholarships.

Lastly, in order to examine the relationship between students' attitudes about U.S. national security and their choice of study abroad destination, this research asked students to indicate if they agreed or disagreed with the following statement "I am concerned about national security issues in the United States." Responses were collected on a nine point scale and re-coded in order to indicate a student's level of concern as low, moderate, or high. Students studying abroad in the MENA region were more likely to note a high level of concern for national security $(36 \%, n=98)$ in comparison with only $18 \%(\mathrm{n}=58)$ of students from more common destinations, $\chi^{2}(2, N=584)=29.96 p=<$ .001 .

Further, there is a relationship between concern for national security and frequency of watching the news. Those who have a high level of concern also indicate that they watch the news often, $\chi^{2}$ 
$(6, N=583)=48.94 p=<.001$. For example, of those students who had a high concern, $46 \%$ of them watch the news often, $21 \%$ sometimes, $17 \%$ rarely, and $15 \%$ never. The opposite trend was seen with those who had low concern with $55 \%$ reporting they watch the news never, $38 \%$ rarely, $38 \%$ sometimes, and $22 \%$ often.

\section{Focus groups}

In addition to the survey data, this research also collected information from a total of 76 study abroad students in the MENA region through focus groups in Egypt, Jordan, and Morocco. A content analysis of all focus group responses was conducted which revealed additional insights into the factors of career intentions, scholarship support, and concern for U.S. national security.

Participants talked frequently about the relationship between their career goals and their choice to study in this region. Many students believed that their study abroad experience would be a marketable experience for them once they began to search for jobs after obtaining their degrees. One student in Egypt noted that living in the region was essential if one wanted to work for the U.S. Foreign Service and that "because of the military there is going to be a lot of security, contracting, and reconstruction work" in the area for which experience in this region will be helpful.

Students also commonly made a connection between Arabic language acquisition and their future careers, particularly jobs in the U.S. Foreign Service. Students expressed the belief that being familiar with the Arabic language and Middle Eastern culture would give them greater opportunities, especially in a difficult job market. One student in Jordan mentioned that when he was in high school the head of the language department encouraged him to consider studying Arabic in college, in order to guarantee him a job right after graduation. Another student bluntly stated:

This is a fact: we wouldn't be doing this [study abroad] if there was [sic] no opportunities for us. Part of the end game is to use language to help with our future careers. For example, the government really recruits Arabic speakers. My Arabic department is very small, but it shoves us toward the government.

There was widespread consensus on this issue, with students often feeding off one another's comments, adding more examples of how Arabic would help them in the future job market.

One student noted that he switched his focus in order to take advantage of these jobs related to the region. He noted "I have always been really interested in Russian, but after 9/11 I started thinking about the opportunities available for people who spoke Arabic and knew about the Middle East, so I switched my focus." Some participants in focus groups also mentioned shifting their focus as a result of receipt of scholarship funds. One student in Egypt noted that "I received the Boren fellowship and then started to shift my career goals based on the opportunity to study abroad with the scholarship."

Many students also made the connection between political events and their career choices. One student noted that if the U.S. did not have a significant presence in the region "then I wouldn't have cared to be here, honestly, because then it isn't relevant to my career." Students, often sheepishly, 
noted that because of conflicts in the region there is an "increasing sense that Arabic is a very marketable job skill." Students talked, perhaps more than any other subject, about the influence of political events such as September 11, 2001 and foreign wars on their decision to study abroad in the region. Many students pointed to the events of September 11, 2001 as the catalyst for their interest in the region and eventually their decision to study abroad in that area. One student in Jordan noted one "could not overestimate the effect that $9 / 11$ had on me and everyone in my generation, it kind of forced us to open our eyes to the world."

\section{Discussion}

As the destinations for study abroad have diversified over the years, there is a need for a greater understanding of the factors which contribute to growth in particular regions. Statistically significant relationships were found between each of the three variables investigated and study abroad destination choice, indicating that students who choose to study abroad in the MENA region are different from their colleagues who choose more common destinations. This research finds that career intentions, scholarship support, and concern for U.S. national security serve to influence whether student will study in the MENA region.

Notably, MENA students differed from their counterparts in common destinations in that they were more likely to prefer to work for the U.S. government in the future, with nearly half of all students who indicated a specific type of organization choosing the government. Students in the MENA region believe their study abroad experience will help them as they enter the job market, particularly when seeking government employment. Further, a large number of MENA students specified that they hope to work for the U.S. State Department or for military intelligence agencies. MENA students often see the Arabic language as a tool to give them an advantage in future careers and also see general experience living in the region as a way to make them desirable government employees. For example, one student in Egypt stated "I want to become a specialist on the Middle East, possibly for the Army, and I thought the best way to understand the Middle East is to live, eat, and survive in the region." There is a pressing need in the U.S. government for Arabic speakers and regional specialists (O'Connell \& Norwood 2007, p. 49). MENA students are adeptly aware of this need and see a direct link between their study abroad experience and a need in government agencies. Some students noted that because of their interest in working for the government, the events of 9/11 determined their area of interest. Since the government has dedicated a great deal of resources (military, aid, diplomacy, etc.) to the MENA region in the last decade, many students believe their job prospects will be improved by obtaining familiarity with the language and culture of the region.

Students who chose the MENA region were more likely to have received scholarship support for their study abroad experience. In addition, notable percentages of students in the region received specific government scholarships. Scholarship funding for students in the MENA region was mentioned much more frequently as essential to their ability to study abroad. In addition, MENA students were more than twice as likely to cite this as a factor in their choice to study in their location. Interestingly, those who had received military or Gilman scholarships also indicated that they would not have gone abroad without these funds, whereas Boren scholars thought they would have studied abroad regardless of the receipt of the scholarship. These scholarships are examples of 
the type of financial incentives that the government is providing in order to encourage students to study in less common destinations, particularly those areas which relate to the current national security interests of the government.

Lastly, students in the MENA region were also significantly more concerned about national security than those in more common destinations. One out of three students in the MENA region reported to be highly concerned about national security, as compared to less than one-fifth of their colleagues in common destinations. Concern for national security was also related to frequency of watching, reading, or listening to the news. Notably half of those who were exposed to the news often also had high concern for U.S. national security, as compared with just one-fifth who had low concern. This concern for national security also goes hand in hand with a higher desire to pursue careers with the U.S. government. Many of the specific jobs students mentioned relate to the mitigation of terrorism via work with civilian and military intelligence agencies. In addition, focus group data revealed that the events of September 11, 2001 have impacted students who chose to study abroad in the MENA region. A recent newspaper article noted that the University of California, Los Angeles has "found that students post-Sept. 11 are increasingly inclined to study abroad" (Zernike 2011). Although students of this generation may be overall more inclined to study abroad, this research suggests that for students who chose the MENA region as a study abroad destination the events of $9 / 11$ and elevated concerns over the national security of the U.S. served as a catalyst for interest in this particular region.

\section{Conclusion}

In recent years, much U.S. political and social attention has been increasingly focused on the Middle East and North Africa. In tandem with geo-political events there have been a growing number of students who are choosing to study abroad in the MENA region. An examination of federal funding for Area Studies, LCTLs, and study abroad has indicated an increasingly strong relationship between the federal government and higher education. Government support has laid the foundation for the expansion of study abroad in the MENA region; an area which has witnessed a remarkable increase of over $500 \%$ in U.S. undergraduate students in the last ten years. ${ }^{9}$

By employing a historical review, this research has described how government has played a role in the expansion of study abroad in this area of the world by increasing the amount of area and language education available at U.S. institutions. In addition, this review has demonstrated ways in which the U.S. government has provided funds for students to study abroad in regions of the world which relate to current national security needs; areas which often are outside of the common destinations in Western Europe and Australia. Survey data from 601 study abroad students in both categories of destinations and focus group discussions with nearly 80 study abroad students in the MENA region reveal that students in the MENA region are more likely to be influenced by government related factors than their counterparts in more common destinations. MENA students were more likely to prefer future careers with the U.S. government, to be supported by government scholarships, and to have high levels of concern for U.S. national security. 
A primary limitation of this study is that of the sampling frame. Given that data was not collected from a random sample, responses can only truly characterize these 601 participants. Despite this limitation, these findings may still provide a useful characterization of these students as well as some of the government related factors influencing study abroad in the MENA region given that the 275 MENA survey participants represent $6 \%$ of all U.S. students studying abroad in this region. Future work which could employ random selection of participants and which investigates a broader range of factors would provide greater certainty of findings and a wider understanding of the role the U.S. government plays in expanding study abroad in this particular region.

One of the primary motivations for study abroad in the MENA region is career advancement, particularly in the government sector. This finding brings to mind long-standing debates among Area Specialists as to the appropriateness of a growing relationship between national security concerns and government support for certain aspects of academia. There is much potential for future research which examines this topic, particularly the long term relationship between study abroad in the MENA region and employment with the U.S. government.

\section{Notes}

${ }^{1}$ Wells (2006) has defined non-traditional destination as those in which few U.S. students study. Non-traditional destinations have been classified as those in Africa, Asia, Latin America and the Middle East. European (both western and eastern) countries are considered the most traditional destinations. This study will refer to those destinations as "common destinations," and includes destinations in Western Europe and Australia.

${ }^{2}$ In this research the Middle East/North Africa (MENA) refers to seventeen countries in the region: Algeria, Bahrain, Egypt, Iraq, Jordan, Kuwait, Lebanon, Libya, Morocco, Oman, Palestinian Territories, Qatar, Saudi Arabia, Syria, Tunisia, the United Arab Emirates, and Yemen. This research does not consider those students who choose Israel as a study abroad destination, as the demographics of students and rational for study in a Jewish state vary from those in other countries in North Africa and the Middle East (see Donitsa-Schmidt \& Vadish 2005).

${ }^{3}$ Data was gathered from students who were currently enrolled in a semester or full academic year program outside of the United States for which they will receive academic credit at their home institution. Other students, such as those who are fully enrolled in universities outside of the U.S. (i.e. someone who transferred to The American University in Cairo), were not included in this study.

${ }^{4}$ NSEA is better known as the "Boren Bill" after Senator David L. Boren (D-OK) who introduced the bill.

${ }^{5}$ The GAO is now known as the Government Accountability Office.

${ }^{6}$ Last update of directory.

${ }^{7}$ A program of the Bureau of Educational and Cultural Affairs of the U.S. State Department.

${ }^{8}$ Given that Boren scholarships are not available to students choosing destinations in Eastern Europe, these students were not included in the analysis of government scholarships as compared with destination choice. Government scholarships in this case refers to Gilman and Military scholarships. 
${ }^{9}$ For example, the Bureau of Education and Cultural Affairs of the U.S. State Department awarded a grant to AMIDEAST in 2010 to help build Cairo University's capacity to host foreign, specifically U.S. study abroad, students.

\section{Bibliography}

Albers-Miller, N., Prenshaw, P., \& Straughan, R. (1999). Student perceptions of study abroad programs: a survey of U.S. colleges and universities. Marketing Education Review, 9, 29-36.

Bourdieu, P. (1986). The Forms of Capital. In J. Richardson (Ed.), Handbook of theory and research for the sociology of education (pp. 242-258). New York: Greenwood Press.

Bradshaw Durrant, M. \& Rasmussen Dorius, C. (2007) Study abroad survey instruments: a comparison of survey types and experiences. Journal of Studies in International Education, 11, 33-53.

Brecht, R. D. \& Walton, A. (2001). National language needs and capacities: a recommendation for action. ”In P. O'Meara, H.D. Mehlinger \& R. M. Newman (Eds.), Changing perspectives on international education, (pp. 103-117). Bloomington: Indiana University Press.

Brecht, R. D. \& Rivers, W.P. (2000). Language and national security in the 21st century: The role of Title VI/Fulbright-Hays in supporting national language capacity. Dubuque: Kendall/Hunt Publishing Company.

Brewer, P. A. (2006). National interest frames and public opinion about world affairs. The Harvard International Journal of Press/Politics, 11, 89-102.

Calhoun, C., LiPuma, E., \& Postone, M. (Eds). (1993). Introduction: Bourdieu and Social Theory. In Bourdieu: critical perspectives, (pp. 1-13). Chicago: The University of Chicago Press.

Chieffo, L. \& Griffiths, L. (2004). Large-scale assessment of student attitudes after a short-term study abroad program. Frontiers: The Interdisciplinary Journal of Study Abroad, 10, 165-177.

Daly, A. J. \& Barker, M. C. (2005). Australian and New Zealand university student's participation in international exchange programs. Journal of Studies in International Education, 9, 26-41.

Desruisseaux, P. (2000). From controversy to quiet prosperity, federal foreign study effort is a survivor. The Chronicle of Higher Education, April 7. Retrieved November 1, 2010, from http://chronicle.com/article/From-Controversy-to-Quiet/35243/

DesJardins, S. L. \& Toutkoushian, R.K. (2005). Are students really rational? The development of rational thought and its application to student choice. In Smart, J.C (Ed.) Higher education: Handbook of theory and research, (pp. 191-240). Dordrecht: Kluwer Academic Publishers.

Dewey, D., Belnap, R. Kirk, Hillstrom, R. (2012-13). Social network development, language use, and language acquisition during study abroad: Arabic language learners' perspectives. Frontiers: The Interdisciplinary Journal of Study Abroad, 22, 84-110.

Eder, J. (2010). Exploring factors influencing student study abroad destination choice. Journal of Teaching in Travel \& Tourism, 10, 232-250.

Ferguson, C. A. (1964). Language study and the Middle East. ANNALS of the American Academy of Political and Social Science, 356, 76-85. 
Forum on Education Abroad. Education Abroad Glossary. Section 2.1. Learning Outside of the Home Campus. Retrieved December 13, 2013 from http://www.forumea.org/EducationAbroadGlossary2ndEdition2011.cfm.

Garver, M. S. and Divine, R. L. (2007). Conjoint analysis of study abroad preferences: key attributes, segments and implications for increasing student participation. Journal of Marketing for Higher Education, 17, 189-215.

Goldstein, S. B. \& Kim, R.I. (2006). Predictors of US college students' participation in study abroad programs: a longitudinal study. International Journal of Intercultural Relations, 30, 507-521.

Goodman, A. (2009). Forward. In R. Lewin (Ed.) The handbook of practice and research in study abroad: Higher education and the quest for global citizenship (pp. ix-x). New York: Routledge.

Hajjar, L. \& Niva, S. (1997). (Re)made in the USA: Middle East studies in the global era. Middle East Report, 205. Retrieved July 18, 2010, from http://www.merip.org/mer/mer205/remade.htm

Hines, R. (2001). An overview of Title VI. In P. O'Meara, H.D. Mehlinger \& R. M. Newman (Eds.), Changing perspectives on international education (pp. 6-10). Bloomington: Indiana University Press.

Hoffa, W. W. \& DePaul, S.C. (Eds.). (2010). Study abroad: 1965-present. Carlisle, PA: Frontiers: The Interdisciplinary Journal of Study Abroad.

Institute of International Education. (IIE) (2007). Current trends in U.S. study abroad \& the impact of strategic diversity issues. IIE Study Abroad White Paper Series, 1.

Institute of International Education. (IIE) (2009a).Expanding study abroad capacity at U.S. colleges and universities. IIE Study Abroad White Paper Series, 6.

Institute of International Education. (IIE) (2009b) Expanding U.S. study abroad in the arab world: Challenges and opportunities. IIE Study Abroad White Paper Series, 4.

Institute of International Education. (IIE) (2010a).Benjamin A. Gilman international scholarship. About the Program. Retrieved September 26, 2010, from http://www.iie.org/en/Programs/Gilman-Scholarship-Program/About-the-Program

Institute of International Education. (IIE) (2010b) Press release: Campuses report early indication that study abroad is rising. Press Center. Retrieved November 20, 2010, from http://www.iie.org/en/Who-We-Are/News-and-Events/Press-Center/Press-Releases/2010/201011-15-Fall-2010-Study-Abroad-Snapshot-Survey

Keller, J. M. \& Frain, M. (2010). The impact of geo-political events, globalization, and national policies on study abroad programming and participation.” In W.W. Hoffa and S. DePaul (Eds) A history of US study abroad: 1965-present, (pp. 15-54). Carlisle, PA: Frontiers: The Interdisciplinary Journal of Study Abroad.

Khoury, P. S. (2000). Current Developments and Future Directions in Middle Eastern Studies. Frontiers: The Interdisciplinary Journal of Study Abroad, 6, 117-126.

Kolb, C. (2009). International studies and foreign languages: a critical American

Priority. In R. Lewin (Ed.) The handbook of practice and research in study abroad: Higher education and the quest for global citizenship, (pp. 49-60). New York: Routledge.

Kramer, M. (2004).Title VI: Turn on the defogger. Sandstorm. Retrieved July 14, 2010, from http://www.geocities.com/martinkramerorg/2004 03 17.htm. 
Larsen, D. \& Dutschke, D. (2010). Campus internationalization and study abroad. In W.W. Hoffa and S. DePaul (Ed.s) A history of US study abroad: 1965-present, (pp. 325-368). Carlisle, PA: Frontiers: The Interdisciplinary Journal of Study Abroad.

Ludden, D. (2000). Area studies in the age of globalization. Frontiers: The Interdisciplinary Journal of Study Abroad, 6, 1-22.

Manski, C. F. (1993). Dynamic choice in social settings. Journal of Econometrics, 58, 121136.(MESA) Middle East Studies Association. (2011). Potential cuts to Title VI and Fulbright Hays funding. MESA board letters and statements. Retrieved May 15, 2010, from http://www.mesa.arizona.edu/about/statements.htm\#funding41811

Mitchell, T. (2004). "The Middle East in the past and future of social science." In D. L. Szanton (Ed.) The politics of knowledge: area studies and the disciplines, (pp. 74-118). Berkeley: University of California Press.(NSEP) National Security Education Program. (2007). 2007 annual report. Retrieved September 14, 2010, from http://www.nsep.gov/support/2007\%20Annual\%20Report.pdf (NSEP) National Security Education Program. (2009). 2008-09 annual report. Retrieved May 15, 2010, from http://www.nsep.gov/about/support/nsep2008.pdf

O'Connell, M. E. \& J. L. Norwood (Eds.). (2007). International education and foreign languages: keys to securing America's future. Washington D.C.: The National Academics Press.

Office of Postsecondary Education, Department of Education. (2008). International education programs service, Title VI programs: building a U.S. international education infrastructure. Retrieved September 19, 2010, from http://www2.ed.gov/about/offices/list/ope/iegps/titlesix.html

Ogden, A.C., Soneson, H.M., \& Weting, P. (2010). The diversification of geographic location. In W.W. Hoffa and S. DePaul (Eds.). A history of US study abroad: 1965-present, (pp. 161-198). Carlisle, PA: Frontiers: The Interdisciplinary Journal of Study Abroad.

Open Doors, Institute of International Education. (2009). 2009 report on international educational exchange. Retrieved March 5, 2010, from http://opendoors.iienetwork.org/?p=150833.

Open Doors, Institute of International Education. (2010). 2010 fast facts. Retrieved November 18, 2010, from http://www.iie.org/en/Research-and-Publications/Open-Doors

Palmer, J. (2012-13). Intercultural competence and language variety on study abroad programs: L2 learners of Arabic. Frontiers: The Interdisciplinary Journal of Study Abroad, 22, 58-83.

Perna, L.W. (2006). Studying college access and choice: A proposed conceptual model. In J.C. Smart (Ed.) Higher education: handbook of theory and research, (pp. 99-157). New York: Springer Press.

Public Law 85-864. (1958). National defense education act (NDEA). United States statutes at large, 72, 1580-1605.

Relyea, C., Cocchiara, F.K. \& Studdard, N.L. (2008). The effect of perceived value in the decision to participate in study abroad programs. Journal of Teaching in International Business, 19, 346-361.

Riddle, W. C. (1992). National security education act of 1991: summary and analysis. CRS report for Congress. Washington, D.C.: Congressional Research Service.

Salisbury, M., Umbach, P., Paulsen, M., \& Pascerella, E. (2008). Going global: Understanding the choice process of the intent to study abroad. Research in Higher Education, 50, 119-143. 
Sanchez, C.M., Fornerino, M., \& Zhang, M. (2006).Motivations and the intent to study abroad among U.S., French, and Chinese students. Journal of Teaching in International Business, 18, 2752.

Sauermann, H. (2004). Vocational choice: a decision making perspective. Journal of Vocational Behavior, 66, 273-303.

Spracher, W.C. (2009). National security intelligence professional education: A map of U.S. Civilian university programs and competencies (Doctoral dissertation). The George Washington University.

U.S. Congress. Senate. (2004). Intelligence Reform and Terrorism Prevention Act of 2004, Section 7112. S. 2485. Retrieved February 23, 2010, from http://www.nctc.gov/docs/pl108_458.pdf

Van Hoof, H.B. and Verbeeten, M. (2005). Wine is for drinking, water is for washing: student opinions about international exchange programs. Journal of Studies in International Education, 9, 42-60.

Vroom, V.H. (1964). Work and motivation. Ney York: Wiley.

Wells, R. (2006). Nontraditional study abroad destinations: analysis of a trend. Frontiers: The Interdisciplinary Journal of Study Abroad, 13, 113-133.

Whitehead, K. D. (2004). Learning the language: Title VI is in need of reform. The National Review Online. Retrieved September 21, 2010, from http://old.nationalreview.com/comment/whitehead200401140823.asp

Wiley, D. (2001). Forty years of the Title VI and Fulbright-Hays international education Programs: building the nation's international experience for a global future." In P. O'Meara, H.D. Mehlinger \& R.M. Newman (Eds.) Changing perspective on international education, (pp. 11-29). Bloomington: Indiana University Press.

Williams, T. R. (2005). Exploring the impact of study abroad on students' intercultural communication skills: adaptability and sensitivity. Journal of Studies in International Education, 9, 356-371.

Zernike, K. (2011). 9/11 inspires student patriotism and celebration. The New York Times. May 3. Retrieved May 3, 2011, from http://www.nytimes.com/2011/05/04/us/04youth.html?pagewanted=2\&hp 